\title{
A Role for the Chemokine Receptor CCR6 in Mammalian Sperm Motility and Chemotaxis
}

\author{
Pedro Caballero-Campo ${ }^{1,5}$, Mariano G. Buffone ${ }^{2}$, Fabian Benencia ${ }^{3}$, José R. Conejo- \\ García $^{4}$, Paolo F. Rinaudo ${ }^{5}$, and George L. Gerton ${ }^{6,}$, \\ ${ }^{1}$ Unidad de Reproducción Humana, Clínica Tambre, Madrid, Spain \\ ${ }^{2}$ Instituto de Biología y Medicina Experimental, National Research Council of Argentina \\ (CONICET), Buenos Aires, Argentina \\ ${ }^{3}$ Heritage College of Osteopathic Medicine Ohio University, Athens, OH, USA \\ ${ }^{4}$ Tumor Microenvironment and Metastasis Program, The Wistar Institute, Philadelphia, PA. USA \\ ${ }^{5}$ Department of Obstetrics, Gynecology, \& Reproductive Sciences, School of Medicine, University \\ of California, San Francisco, CA, USA \\ ${ }^{6}$ Center for Research on Reproduction and Women's Health, Perelman School of Medicine at the \\ University of Pennsylvania, Philadelphia, PA, USA
}

\begin{abstract}
Although recent evidence indicates that several chemokines and defensins, well-known as inflammatory mediators, are expressed in the male and female reproductive tracts, the location and functional significance of chemokine networks in sperm physiology and sperm reproductive tract interactions are poorly understood. To address this deficiency in our knowledge, we examined the expression and function in sperm of CCR6, a receptor common to several chemoattractant peptides, and screened several reproductive tract fluids for the presence of specific ligands. CCR6 protein is present in mouse and human sperm and mainly localized in the sperm tail with other minor patterns in sperm from mice (neck and acrosomal region) and men (neck and midpiece regions). As expected from the protein immunoblotting and immunofluorescence results, mouse Ccr6 mRNA is expressed in the testis. Furthermore, the Defb29 mRNA encoding the CCR6 ligand, $\beta$-defensin DEFB29, is expressed at high levels in the epididymis. As determined by protein chip analysis, several chemokines (including some that act through CCR6, such as CCL20/ MIP-3a (formerly Macrophage Inflammatory Protein 3a) and protein hormones were present in human follicular fluid, endometrial secretions, and seminal plasma. In functional chemotaxis assays, capacitated human sperm exhibited a directional movement towards CCL20, and displayed modifications in motility parameters. Our data indicate that chemokine ligand/receptor interactions in the male and female genital tracts promote sperm motility and chemotaxis under noninflammatory conditions. Therefore, some of the physiological reactions mediated by CCR6 ligands in male reproduction extend beyond a pro-inflammatory response and might find application in clinical reproduction and/or contraception.
\end{abstract}

"Correspondence and reprint requests: George L. Gerton, Ph.D., Center for Research on Reproduction and Women's Health, Department of Obstetrics and Gynecology, Perelman School of Medicine, University of Pennsylvania, 421 Curie Blvd., 1309 BRB II/ III, Philadelphia, PA 19104-6160, gerton@ mail.med.upenn.edu, (215) 573-4781.

Final version of this study was presented at the 2012 Frontiers in Reproduction (FIR) $15^{\text {th }}$ Anniversary Symposium (Marine Laboratory, Woods Hole, MA, USA).

The authors have declared that no competing interests exist. 


\section{Keywords}

Chemokines; $\beta$-defensin; sperm motility; chemotaxis; capacitation

\section{Introduction}

A mammalian spermatozoon must locate the female gamete and deliver its genetic material to generate a new individual. The interaction of motile sperm with the oocyte - both at a distance and through physical interaction - represents a series of integrated processes designed to deliver sperm with optimal fertilizing potential to the site of fertilization. Sperm movement patterns appear to depend on external regulatory factors secreted by the oocyte or its surrounding cells that influence sperm motility (chemokinesis) and chemotaxis, which would optimize gamete interactions (Eisenbach, 1999; Eisenbach and Giojalas, 2006; Kaupp, 2012). The development of the fertilization-competent state occurs through an incompletely understood process called "capacitation," which refers to the physiological changes that render spermatozoa competent to fertilize an egg (Visconti et al., 1998, 2011). Precontact communication by chemotaxis has been demonstrated between gametes in pig, rabbit, human, and mice (Cohen-Dayag et al., 1995; Lee et al., 1994; Sliwa, 1995; Spehr et al., 2003; Teves et al., 2010). The involvement of different molecules in chemokinesis and in the chemotactic attraction of human sperm to the oocyte is a fascinating and evolving concept.

The substances secreted by the male and female reproductive tracts that influence sperm behavior, physiology, and viability are coming to light, as techniques to screen for various substances in biological fluids are developed and improved. For instance, human seminal plasma contains a variety of inflammatory cytokines, which are thought to confer a survival advantage to spermatozoa within the female genital tract (Denison et al., 1999).

Chemokines, a family of chemotactic cytokines produced by a wide variety of cell types, have the ability to attract cells in response to the activation of specific cell surface receptors (Baggiolini, 1998). Several types of mammalian $\beta$-defensins have also been found in male reproductive tissues (Conejo-Garcia et al., 2004; Li et al., 2001; Rodríguez-Jiménez et al., 2003). Multiple $\beta$-defensins have been independently identified as functional ligands for the chemokine receptor CCR6 (Conejo-Garcia et al., 2004; Röhrl et al., 2010a; Taylor et al., 2009; Yang et al., 1999) and, more recently, for CCR2 (Röhrl et al., 2010b).

Chemokine receptors belong to the superfamily of G protein-coupled receptors (GPCR). These canonical receptors have seven transmembrane sequences of 20-25 hydrophobic residues that form a-helices within the plasma membrane, an extracellular $\mathrm{N}$-terminus, three extracellular loops, three intracellular loops, and a C-terminal cytoplasmic tail. These receptors transmit information to the cell about the presence of chemokine gradients in the extracellular environment. They are named depending on the structure of their ligand (CXC, $\mathrm{CC}$ or $\mathrm{CX} 3 \mathrm{C}$ ). The binding of a chemokine or chemoattractant peptide such as a $\beta$-defensin to its cognate receptor is followed by the involvement of heterotrimeric $\mathrm{G}$ proteins (Reif and Cantrell, 1998; Ward and Westwick, 1998) and the triggering of pathways involving intracellular second messengers such as cAMP and calcium.

The molecular mechanisms involved in the chemoattraction of specific sperm subsets prior to fertilization remain unknown. Moreover, the location and functional significance of chemokines and chemokine receptors in sperm physiology and male and female genital tracts are poorly understood. It is clear that sperm motility characteristics are modified in response to changes in the microenvironment as the sperm move through the male and female genital tracts. Furthermore, human seminal plasma has potent anti-inflammatory 
properties, which are thought to confer a survival advantage to spermatozoa within the hostile female genital tract (Kelly, 1995, Robertson et al 2007).

In this study, we identified the presence of receptor CCR6, and its chemoattractant ligands (CCL20 and $\beta$-defensins) in human and mouse spermatozoa as well as in the gamete microenvironment during capacitation. We also show that mouse Defb29, previously characterized by one of us (Conejo-Garcia et al., 2004), is highly expressed in the cauda epididymis. Our results provide evidence that, in addition to their role in inflammation, certain $\beta$-defensins and chemokines have specific functions through ligand/receptor interactions in sperm motility and chemotaxis acting in the male and female reproductive tracts.

\section{Materials and Methods}

\section{Collection and analysis of human semen samples}

Human semen samples were obtained by masturbation from healthy donors with proven fertility after 2-5 days of abstinence. The samples were collected in sterile containers and evaluated within $1 \mathrm{~h}$ after ejaculation following World Health Organization guidelines (World Health Organization, 2010). Briefly, semen analysis included evaluation of volume, concentration, motility, morphology, viscosity, and leukocyte count. Semen parameters were consistently superior to WHO reference values, and leukospermia was not found in any of the analyzed samples. Informed consent to use semen samples was obtained from each participant in this study and collection of semen was approved by the University of Pennsylvania Institutional Review Board. To prepare seminal plasma, liquefied semen samples were first centrifuged at $1,000 \times g$ for $5 \mathrm{~min}$, after which the supernatants were recentrifuged at $10,000 \times g$ for 15 min to remove cellular elements and debris. After centrifugation, the seminal plasma was collected and stored at $-80^{\circ} \mathrm{C}$ until used. For capacitation, sperm samples were prepared as previously described (Caballero-Campo et al., 2006).

\section{Follicular and endometrial fluids}

Human follicular fluid $(\mathrm{FF})$ and endometrial fluid samples were obtained from women whose routine infertility examination revealed no abnormal findings, and who were undergoing transvaginal follicular aspiration for IVF due to male infertility as previously described (Simón et al., 1996). Fluids were collected under an Institutional Review Board protocol for samples that would otherwise be discarded. No patient identifiers were used in the sample collection nor was specific patient information received. Women with endometriosis, polycystic ovary syndrome, or infectious diseases were excluded from this study. The FF obtained from follicles of $>16 \mathrm{~mm}$ diameter were pooled, immediately centrifuged for $5 \mathrm{~min}$ at $1,500 \times \mathrm{g}$, and then filtered through a $0.5 \mu \mathrm{m}$ disc filter to remove cells and debris. The filtrates were aliquoted and stored at $-20^{\circ} \mathrm{C}$ until used.

\section{Mouse samples}

Adult (>12 weeks old) CD-1 male mice were purchased from Charles River Laboratories, Inc. (Wilmington, MA). Mice were used in accordance with the International Guiding Principles for Biomedical Research Involving Animals as promulgated by the Society for the Study of Reproduction, and research protocols involving animals were approved by the University of Pennsylvania Institutional Animal Care and Use Committee.

\section{Indirect immunofluorescence (IIF) and flow cytometry}

Mouse cauda epididymal sperm and ejaculated human sperm were analyzed by indirect immunofluorescence (Kim et al., 2001) and flow cytometry (Griffiths et al., 2008). 
Noncapacitated and capacitated mouse and human sperm samples were washed for $5 \mathrm{~min}$ at $300 \times g$, resuspended in PBS, and attached to poly-L-lysine-coated slides. Spermatozoa were fixed (4\% paraformaldehyde in PBS) for 15 min. After washing in PBS, slides were blocked with PBS containing $600 \mu \mathrm{g} / \mathrm{ml} \mathrm{BSA}$ for $30 \mathrm{~min}$ at room temperature. The slides were then incubated for $1 \mathrm{~h}$ at $37^{\circ} \mathrm{C}$ in a humidified chamber with primary antibody (mouse antihuman CCR6 catalog number MAB195 or rat anti-mouse CCR6 catalog number MAB590, R\&D Systems, Minneapolis, MN) diluted in blocking buffer 1:100. Slides incubated without first antibody in $10 \%$ normal goat serum were used as negative controls. After three washes in PBS, the slides were incubated in blocking buffer containing FITC-goat anti-mouse IgG (1:5000) and FITC-goat anti-rat IgG (1:5000) (Santa Cruz Biotech) for $1 \mathrm{~h}$. Following several washes in PBS, sperm were examined by phase contrast/fluorescence microscopy (modified from Kim et al. (2001)). Analysis by flow cytometry of cells labeled with the antibodies was carried out as described by Lasso et al. (1994) with a FACSCalibur flow cytometer with CellQuest 3.2.1fl software (Becton Dickinson).

\section{Immunoblotting}

Mouse and human sperm proteins were separated by SDS-PAGE according to the method of Laemmli (1970) and transferred to Immobilon (PVDF) transfer membranes (Towbin et al., 1979; Turner et al., 1999, 2001). Blots were blocked in 5\% non-fat dry milk in Tween-Tris buffered saline (TTBS) and incubated overnight at $4{ }^{\circ} \mathrm{C}$ with primary antibody (goat antihuman/mouse CCR6, Catalog number C10129, Capralogics, Gilbertville, MA) in blocking buffer 1:500. Blots were then treated with secondary antibody (horseradish peroxidaseconjugated chicken anti-goat IgG, Santa Cruz Biotechnology, Santa Cruz, CA) in TTBS buffer (1:2000) for $1 \mathrm{~h}$ at room temperature, and developed using enhanced chemiluminescence (ECL) substrate (Pierce). Bound antibody was visualized by chemiluminescence exposure of X-ray film. In some experiments blots were developed using enhanced chemifluorescence (ECL Plus RPN2132) substrate (Amersham), utilizing a novel acridine-based chemistry and horseradish peroxidase to generate a light signal and also a stable fluorescent product that can be visualized by chemifluorescence densitometry (blue laser) on a Storm 860 phosphoimager (Molecular Dynamics. Sunnyvale, CA).

\section{Quantification of mRNA by real-time RT-PCR}

Samples from mouse testes and the different parts of the epididymis (caput, corpus, cauda) were used to study the expression of Defb29 (GenBank accession number AF515626) compared to other male and female tissues by real-time quantitative RT-PCR (ConejoGarcia et al., 2004) Levels of mRNA encoding various gene products were determined by real-time RT-PCR as previously described by García et al. (2001). Briefly, after RNA extraction, complementary DNA was generated by reverse transcription with TaqMan ${ }^{\circledR}$ and SYBR ${ }^{\circledR}$ Green One-Step Real-Time RT-PCR Master Mix (Applied Biosystems, Foster City, CA). Complementary DNA primers were designed using Primer3 software (http:// frodo.wi.mit.edu/). The primers used were previously designed as Defb29: (forward: 5'CTG ATC CTG GTT GAC GAG ACC-3'; reverse: 5'-CTG GTA AAG CTC ACA CGC AAT C-3') and Gapdh: (forward: 5'-CCT GCA CCA CCA ACT GCT TA-3'; reverse: 5'CAT GAG TCC TTC CAC GAT ACC A-3') (Conejo-Garcia et al., 2004; Cubillos-Ruiz et al., 2009). For Ccr6, the primers were (forward: 5'-GGA CTG AGA GCC CTG GAA AG3'; reverse: 5'-CTT GAA TGG CAG ACA CTC ACA GT-3'). Standard curves for Defb29, $C c r 6$, and Gapdh were constructed. Two microliters of RT product were used for real-time PCR. The amplification reaction $(25 \mu \mathrm{l})$ contained RT product, forward primer, and reverse primer. Reactions were performed with previously established thermal cycling conditions in the ABI 7700 Sequence Detector (Applied Biosystems). Collection and analysis of data were performed with ABI 7700 sequence detector software. 


\section{Detection of chemokines in human reproductive fluids}

To evaluate the presence of chemokines in seminal plasma (4 specimens), follicular fluid (3 specimens), and endometrial fluid ( 3 specimens), samples were analyzed with the RayBio Human Cytokine Antibody Array I and IV membranes (RayBiotech, Norcross GA), which allow the detection of 42 and 38 different cytokines and chemokines, respectively. Membranes were analyzed following the manufacturer's instructions. Briefly, membranes with pre-spotted capture antibodies were incubated with samples for $2 \mathrm{~h}$ at room temperature. Chemokines were detected by incubation with biotinylated detection antibodies for another $2 \mathrm{~h}$ at room temperature. Following addition of horseradish peroxidaseconjugated streptavidin and overnight incubation at $4{ }^{\circ} \mathrm{C}$, signals were revealed by ECL and (ECL Plus RPN2132 substrate Amersham). ECL Plus can be visualized by chemifluorescence densitometry (blue laser) on a Storm 860 phosphoimager (Molecular Dynamics. Sunnyvale, CA). Positive controls included in the blot were used to normalize the results from different membranes.

\section{Evaluation of human sperm motility changes after treatment with ligands for CCR6}

To demonstrate a functional role for CCR6 in human sperm, we investigated the dynamic response of capacitated spermatozoa to treatment with several CCR6 ligands. To perform an objective evaluation, computer assisted sperm analysis (CASA; IVOS system version 12, Hamilton-Thorne Biosciences, Beverly, MA) was performed to assess changes in motility patterns after exposure to CCR6 ligands. The kinetic parameters classify sperm movement into different types of progressive motility as "rapid" or "slow" according to the CASA settings, and as "hyperactivated" motility using the criteria defined previously (Burkman, 1991; Caballero-Campo et al., 2006). Capacitated human sperm samples were incubated with the ligands for CCR6 to assess effects on sperm motility kinetics and chemotaxis. After capacitation, 10 million cells per $\mathrm{ml}$ were incubated with increasing concentrations $(0,10$, $100,1000 \mathrm{pg} / \mathrm{ml}$ ) (Isobe et al., 2002) of recombinant human CCL20 (R\&D Systems, Minneapolis, MN), recombinant human DEFB4A (also known as DEFB2, formerly hBD-2; Catalog No. HBD25-R from Alpha Diagnostics International, San Antonio, TX) (Hoover et al., 2002; Pérez-Cañadillas et al., 2001) and human DEFB103A (also known as DEFB3, formerly hBD-3; Catalog No. HBD37-R from Alpha Diagnostics International) (García et al., 2001) proteins diluted in $\mathrm{HTF}$ medium at $37^{\circ} \mathrm{C}$ and $5 \% \mathrm{CO}_{2}$. As a control, several dilutions of FF were used. At the end of the incubation times, manual motility assessments (World Health Organization, 2010) were performed on sperm from different concentration treatments. The $1,000 \mathrm{pg} / \mathrm{ml}$ point was chosen as the working concentration for the following motility assay experiments. The motility patterns of capacitated sperm were examined with a double sperm motility and chemotactic evaluation approach, after treatment with ligands for CCR6. The analysis of sperm motility parameters was performed using CASA. For this evaluation, $5 \mu \mathrm{l}$ aliquots of treated or control sperm samples were placed in a $20 \mu \mathrm{m}$ depth standard count analysis chamber (Leja Products, Nieuw-Vennep, The Netherlands) that had been preheated at $37^{\circ} \mathrm{C}$, and analyzed using the CASA system with settings according to the manufacturer's instructions. For every sample, approximately 10 randomly selected fields were evaluated for a minimum total of 300 sperm. Average values were obtained for sperm motion parameters such as: curvilinear velocity (VCL), straightline velocity (VSL), average path velocity (VAP), amplitude of lateral head displacement (ALH), linearity (LIN=VSL/VCL), and straightness (STR=VSL/VAP). Progressive motile sperm were defined by values of VAP $>20 \mu \mathrm{m} / \mathrm{s}$ and STR $>80 \%$. Rapid or slow motile sperm cells were classified according to the CASA standard cutoff values for VAP and VSL. Slow cells were defined as cells with either of the following attributes: VAP $<20 \mu \mathrm{m} / \mathrm{s}$ or VSL $<30 \mu \mathrm{m} / \mathrm{s}$. In addition, we also analyzed individual parameters and recorded sperm tracks (Caballero-Campo et al., 2006). 


\section{Chemotaxis}

To investigate the chemotactic effect of CCL20, the percentage of chemotactic sperm after the different treatments was analyzed by the directionality-based method described by Fabro et al., (2002), with minor modifications, using the Zigmond chemotaxis chambers

(Zigmond, 1977). These devices, kindly provided by Dr. Sally Zigmond of the University of Pennsylvania, consist of two wells separated by a partition wall and closed with a cover slip. As a control for human sperm chemotaxis, we used follicular fluid, which is well-established as a sperm chemoattractant (Cohen-Dayag et al., 1995; Eisenbach and Tur-Kaspa, 1999; Makler et al., 1992; Ralt et al., 1991; Villanueva-Diaz et al., 1990). Briefly, the system allows the formation of a concentration gradient of the chemoattractant test substance between both compartments. The spermatozoa are put in one well, whereas the testing well is filled with FF or a CCR6 ligand. The movement of the cells in the partition wall separating the wells is recorded at $10 \mathrm{X}$ magnification. Our video microscopy system consists of an inverted microscope Nikon TE2000 equipped with a Princeton Instruments MicroMax CCD camera with a time-lapse video recorder (Roger Scientific, Trenton NJ) (Buffone et al., 2009). The system allows the formation of a concentration gradient from the one well, filled with the chemoattactrant (CCL20), to the other well, filled with spermatozoa (capacitated sperm). Sperm cells were recorded onto the partition wall (in the middle of the two wells) at using a 10X objective for 10-15 minutes. As controls for human sperm chemotaxis, we used FF which is a well-established sperm chemoattractant (Eisenbach and Tur-Kaspa, 1999), and non-capacitated human sperm cells as negative control, only capacitated cells are chemotactically responsive (Cohen-Dayag et al., 1995). In each recording, the sperm tracks where analyzed semiautomatically (Fabro et al., 2002) for 5-10 minutes after the distribution of the cells was stable. Defining X-axis as the direction of the gradient, the tracks were analyzed as the percentage of the cells traveling longer distance in the direction of the chemoattractant gradient than in the gradient-less direction, perpendicular defined by $\mathrm{Y}$-axis. We evaluated the chemotactic sperm tracks using a grid, in by the means of the percentage of cells having $\Delta \mathrm{X} / \Delta \mathrm{Y}>1( \pm \mathrm{SD})$, apart from the sperm speed and pattern of movement (Fabro et al., 2002). The results shown in Figure 7 correspond to 4 independent experiments from two donors. In addition, under the same CCL20 and FF treatment conditions as for sperm motility evaluation, we analyzed individual motility parameters and recorded sperm tracks (Caballero-Campo et al., 2006). All data were transferred and processed in Excel files prior to statistical analysis.

\section{Statistical analysis}

The Statistical Package for the Social Science (SPSS Inc., Chicago, IL) was used for statistical analysis. The analysis of variance (ANOVA) for multiple comparisons was carried out between groups and $p<0.05$ was considered statistically significant.

\section{Results}

\section{Reproductive fluids contain multiple chemoattractant peptides}

To define the presence of chemokines in reproductive fluids, we performed protein arrays using human seminal plasma, endometrial fluid, and follicular fluid. An unexpectedly high number of chemokines were identified in fluids from both the female and male genital tracts. These included the specific CCR6 ligand CCL20, as well as CXCL8 (interleukin 8), CX3CL1 (fractalkine), and CCL2 (monocyte chemotactic protein 1), traditionally associated with the recruitment of multiple immune cell populations. In addition, CCL5 (RANTES) was found in follicular fluid, but not in seminal plasma nor endometrial fluid (Figure 1). Relevant expressions patterns for IL-8, CCL2/MCP-1, CCL5/Rantes, CXC3CL1/ Fraktalkine, and CCL20/MIP-3a are summarized in Table 1. 
In complementary studies in mice, we next determined the expression of the corresponding receptors in a variety of tissues, and we found that $C c r 6 \mathrm{mRNA}$ is expressed at high levels in the testis but it was undetectable in samples from the uterus (Figure 2A). To define the expression of alternative CCR6 ligands in reproductive tissues, we focused on the unknown expression pattern of the Defb29 mRNA encoding mouse DEFB29, a proven CCR6 ligand and the counterpart of human DEFB116 (Conejo-Garcia et al., 2004). Surprisingly, the highest level of Defb29 expression was found in the cauda epididymis, relative to any other tissue (Figure 2B). Defb29 mRNA was also expressed by other regions of the epididymis at significantly lower levels.

\section{CCR6 is localized in flagella of mouse and human spermatozoa}

Because Ccr6 mRNA is expressed in the male mouse genital tract, but not at detectable levels in uterine tissue, we next aimed to define the presence and localization of the CCR6 protein in mouse and human sperm. Indirect immunofluorescence revealed that CCR6 was clearly detected in human sperm and was mainly localized in the tail and in the postacrosomal region (Figure 3A). CCR6 was also found in the midpiece and basal region (neck) in a small percentage of sperm cells. In mouse sperm, CCR6 was also primarily identified in the principal piece and neck region of the tail, although a small percentage of sperm cells showed staining in the acrosomal area (Figure 4A).

Curiously, some human sperm cells did not display detectable CCR6 signal. In examining this issue further, it appeared that the detectability of CCR6 may be related to the state of sperm capacitation. To address this in an objective manner, we utilized flow cytometry analysis of human and mouse sperm before and after capacitation (Figure 3B, Figure 4B). In sperm from both species and states of capacitation, we found two subpopulations of sperm that differed in their staining with antibody to CCR6. Following capacitation, the more intensely labeled sperm became more abundant, suggesting that capacitation causes the exposure or unmasking of epitopes recognized by the CCR6 antibodies. Thus, the percentage of sperm showing CCR6 staining may reflect different levels of sperm maturation. Alternatively, the variability could result from differences in the expression levels of the protein from cell to cell during spermatogenesis, from contributions by epididymosomes during transit through the epididymis, or from the mixing with prostasomes during ejaculation (human only). Immunoblotting analyses confirmed the presence of CCR6 in mouse and human sperm with the expected molecular weights (Figure 5). Therefore, the chemokine receptor CCR6 was present mainly in the tail of sperm cells, where it may play a role in sperm motility as a chemokine sensor.

\section{CCR6 ligands alter sperm motility patterns and promote chemotaxis}

CASA demonstrated that the number of sperm showing kinetic parameters related to progressive motility (VSL and VAP) was higher after CCL20 treatment compared to the rest of the treatments (FF and $\beta$-defensins) (Figure 6). Moreover, maximal chemotactic responsiveness was observed with CCL20. CASA analysis showed that the percentage of cells with a progressive motility pattern also increased after CCL20 treatment. In FF treated cells, the percentage showing a linear swimming pattern decreased, whereas the percentage of hyperactivated sperm increased. On the other hand, motility pattern changes were negligible after treatment with DEFB4 and DEFB103A (also known as DEFB2 and DEFB3), both of which are known ligands of CCR6, although these are considered weaker than CCL20 (Ghannam et al., 2011; Yang et al., 1999) (Figure 7). Therefore, CCR6displaying sperm cells increase their motility in response to the CCR6-specific chemokine ligand CCL20, demonstrating that CCR6 is functional in sperm and may also respond to CCL20 in fluids from the male and/or female genital tracts. 


\section{Discussion}

Before fertilization, sperm must receive and process environmental signals to locate the oocyte (Yanagimachi, 1994). Experiments performed in sea urchin and in other marine species (Guerrero et al., 2010; Kaupp et al., 2003), demonstrated that these chemoattractants originate from the oocyte and its surrounding investments (Sun et al., 2005). In addition, seminal plasma is not just a carrier for spermatozoa. It contains high concentrations of cytokines, chemokines, and other biological compounds that are able to exert potent effects on the immune system of the receptive partner (Robertson et al., 2006; Sharkey et al., 2012). Previous studies have shown that semen induces an acute inflammatory response at the female genital mucosa after coitus in mammals (for review Robertson et al. (2007), including humans (Sharkey et al., 2012). The interactions of the sperm with these chemoattractants primarily influence sperm movement, directing the sperm to the site of fertilization.

Potential chemoatractant molecules (chemokines and $\beta$-defensins) also arise from the reproductive tract, as shown in the present study. Chemokines are involved in several human reproductive events (García-Velasco and Arici, 1999; Simón et al., 1998), including regulatory mechanisms that allow the embryo to grow and develop in the uterus (CaballeroCampo et al., 2002; Dominguez et al., 2003), and also sperm chemotaxis (reviewed by Eisenbach and Giojalas (2006)). Although $\beta$-defensins have been described in association with sperm, the function of the $\beta$-chemokine receptor CCR6 and its specific ligand CCL20 have never been characterized in sperm, normal reproductive tissues, or genital tract fluids.

In the present study, we found that Ccr6 mRNA is expressed in the mouse testis, and the protein was located on the plasma membrane of mouse and human sperm. These results were confirmed by immunoblotting analyses. We believe that the majority of CCR6 in human and mouse sperm originate in the spermatogenic cells based upon our RNA expression studies (Figure 2) and data available at the Mammalian Reproductive Genetics website at the University of Washington [http://mrg.genetics.washington.edu/index.cgi? mrg_id=328109] although it is formally possible that that some CCR6 is contributed to the sperm by epididymosomes (Sullivan et al., 2007). In both species, the receptor was primarily localized to the principal piece of the tail, which represents the first evidence for the presence of CCR6 on the surface of human and mouse spermatozoa. This region is involved in motility and hyperactivation, a specialized motility pattern associated with capacitation (Suarez, 1996). Moreover, using flow cytometry with non-capacitated and capacitated sperm, we determined that the ability of the anti-CCR6 antibody to detect the protein was dependent on the capacitation state of the sperm. In studies with other cytokine receptors, such as CX3CR1, only half of the sperm population was found positive for the receptor (Zhang et al., 2004). Based on this prevalence, it was suggested that chemokine receptor cell surface levels vary according to receptor endocytosis and recycling (Oppermann, 2004). However, we propose that chemokine receptor detection on the sperm surface may actually be dependent upon the capacitation state of the individual sperm cell.

With demonstration of the presence of CCR6 on the surface of human and mouse sperm, we next looked at whether ligands for this receptor were expressed in the male and female reproductive tract fluids. We found the CCR6-specific ligand CCL20 in human seminal plasma, endometrial fluid, and follicular fluid. As previously described, other chemokines such as CX3CL1, CXCL8, CCL5, and CCL2 were also detected in these reproductive fluids (Caballero-Campo et al., 2002; García-Velasco and Arici, 1999; Isobe et al., 2002; Kawano et al., 2001; Zeyneloglu et al., 1998; Zhang et al., 2004). Seeking to identify the presence of alternative CCR6 ligands in mouse reproductive tissues, we focused on mouse DEFB29, which is the $\beta$-defensin with the clearest human counterpart in terms of sequence similarity 
(DEFB116). DEFB29 is a proven CCR6 ligand (Conejo-Garcia et al., 2004) and the expression patterns of either mouse DEFB29 or human DEFB116 (human counterpart) were previously completely unknown. As shown in this study, we now know that the mRNA encoding mouse DEFB29 is very highly expressed in the cauda epididymis.

The $\beta$-defensins have been mostly described in the male (Patil et al., 2005), but they are also found in the female genital tract (Quayle et al., 1998; Valore et al., 1998). In the female mouse endometrium, $\beta$-defensins are regulated by estradiol (Soboll et al., 2006). In addition, the expression of $\beta$-defensins in the human endometrium varies in relation to the stage of the menstrual cycle (King et al., 2003). This is similar to what we have previously seen with chemokines (Caballero-Campo et al., 2002). This suggests a common regulatory role for these molecules in reproductive tract maintenance, host defense, and also fertility (García et al., 2001; Yudin et al., 2005). It is possible that chemokines and $\beta$-defensins modulate sperm-oocyte or sperm-reproductive tract interactions as well as sperm motility (Eisenbach and Giojalas, 2006; Tollner et al., 2008a, 2008b, 2012). Moreover, mutations in certain human $\beta$-defensins may cause impaired sperm function and subfertility (Tollner et al., 2011). In particular, we hypothesized that these molecules play a role in sperm physiology while protecting the male reproductive tract from invading microbial pathogens. In addition, we demonstrated that CCR6 specific ligands were relevant for sperm motility and sperm-egg interactions, unveiling their potential contribution to the pre-fertilization processes. We employed the previously described directionality-based assay (videomicroscopy in a Zigmond chamber) for sperm chemotaxis (Fabro et al., 2002; Zigmond, 1977) and CASA analysis of sperm motility parameters (Caballero-Campo et al., 2006). Capacitated sperm were treated with human follicular fluid and the recombinant CCR6 specific ligands (CCL20 and $\beta$-defensins). Furthermore, human FF was used as a source of substances secreted from the egg and its surrounding cells, including CCL20 as shown in this study. We found that capacitated cells respond chemotactically to a gradient of human FF, which is in agreement with earlier studies (Fabro et al., 2002; Giojalas and Rovasio, 1998; Ralt et al., 1991). These investigations also described the independence of chemotactic responsiveness from other kinetic behaviors (chemotaxis versus chemokinesis), such as hyperactivation, due to the presence of progesterone in FF (Jaiswal et al., 1999; Mbizvo et al., 1990). Significantly, the chemotactic response was more intense to CCL20 compared to FF, exhibiting an increase in the number of progressively motile sperm and illustrating the absence of an effect on hyperactivation. In future studies, the effects of CCL20 on motion of hyperactivated sperm should be more thoroughly studied in light of recent observations suggesting that hyperactivation is part of the chemotactic response (Armon and Eisenbach, 2011).

Human $\beta$-defensins use the same receptor (CCR6) as does the chemokine CCL20, suggesting that these proteins share similar structural features and, possibly, an analogous mechanism of receptor recognition and activation. Comparison of the structures of both human and murine $\beta$-defensins with human and murine CCL20 indicated a single aspartate (Asp 1 in human DEFB1), followed by the hydrophobic residue Tyr3 or Val6 (DHYNCV motif in human DEFB1), as a potentially important determinant of CCR6-mediated chemotactic activity of defensin. The DHYNCV fragment is equivalent to the DCCL motif in CCL20, and in human DEFB1(Hoover et al., 2002; Pérez-Cañadillas et al., 2001; Rodríguez-Jiménez et al., 2003). These proteins chemoattract and regulate dendritic cells through binding the CCR6 receptor (Yang et al., 1999). Recently, mononuclear phagocytes with properties similar to dendritic cells have been located in a dense network at the base of the epididymal epithelium in the mouse (Da Silva et al., 2011).

CCR6 characterization experiments were performed using an antipeptide antibody. The region used as an antigen corresponds to amino acid residues 18-46 of human CCR6, and the antibody also cross-reacts with the mouse orthologue. CCR6-deficient mice appear to be 
healthy and breed well (Cook et al., 2000; Varona et al., 2001). However, as far as we know, no specific studies on reproduction and sperm function have been reported. Multiple sequence alignments with other chemokine receptor sequences showed approximately $38 \%$ amino acid identity with the a-chemokine receptors hCXCR1 and hCXCR2, which represents only slightly more identity than the closest $\beta$-chemokine receptor hCCR4, which is approximately $36 \%$ identical (Greaves et al., 1997). The similarity between the human and murine CCR6 sequences is $73.8 \%$ over the entire sequence (Varona et al., 1998). However, hDEFB4 and hDEFB103A, together with their mouse orthologues (mDEFB4 and mDEFB14), are chemotactic for a broad spectrum of leukocytes in a CCR6- and, also, CCR2-dependent manner (Röhrl et al., 2010a). Expression of several chemokine receptors in sperm has been previously reported (Muciaccia et al., 2005; Zhang et al., 2004;

Zuccarello et al., 2011). Taken together, our results suggest that $\beta$-defensins and chemokines present in reproductive fluids may modulate sperm movement through interaction with their cognate receptors in the membrane of the sperm cells.

Functional experiments with capacitated human sperm in the present study indicated that CCR6 and specific ligands might be involved in motility changes related to the capacitation process, especially kinetic alterations and chemotaxis. Thus, the CCR6 location in sperm might potentially identify capacitated sperm subpopulations (Eisenbach, 1999). Considering that receptors for progesterone and mannose identify a subset of sperm (Aitken, 1994; Benoff et al., 1993), it might be possible that functionally viable sperm express receptors, e.g., CCR6 or other G-protein coupled receptors such as olfactory receptors (Spehr et al., 2003).

The interaction of motile human sperm with the oocyte represents a series of integrated processes designed to deliver sperm with optimal fertilizing potential to the site of fertilization. These functions may be extremely significant from a medical standpoint. Determining the prevalence of these factors in fertile and infertile patients might provide relevant clinical information about certain mechanisms of male reproductive function and dysfunction. More importantly, these molecules could play a role in the etiology of idiopathic immunological infertility and may provide tools for its specific diagnosis and possible treatment. In addition, these mechanisms may expose new targets for contraceptive interventions. Ongoing studies will elucidate the molecular signaling pathways associated with these receptors in human and mouse sperm.

\section{Acknowledgments}

The authors would like to thank Dr. Caballero-Peregrin and the Andrology Laboratory group at Clinica Tambre (Madrid, Spain) with human sperm analysis assistance. We also thank Prof. Gerton and Prof. Rinaudo laboratory members for their technical help, especially Xiaoe Liu with immunoblotting. PCC is very grateful to instructors and participants of the 2012 FIR course and Symposium for technical assistance and constructive criticism, and Fundacion Tambre for research funding. PCC would also like to thank Professors Luis Blasco and Jerome Strauss for their encouragement to work in the Center for Research on Reproduction and Women's Health. We dedicate this study to Professor Emeritus Bayard T. Storey on the occasion of his $80^{\text {th }}$ birthday; Professor Storey was a wonderful resource and advisor during the execution of these studies.

Support: This study was supported in part by CONRAD (GLG), NIH HD-41552 (GLG), Beca de Investigación 26302 from Fundación Salud 2000 and Fundación Tambre, Madrid, Spain (PCC); NIH RO1TW008662 and PICT 2010-2426 from Agencia Nacional de Promoción Científica y Tecnológica, Buenos Aires, Argentina (MGF); NIH 15 CA137499-01 and NSF CBET-1039869 (FB); NCI 2RO1CA124515, NCI RO1CA157664, and DoD grant OC100059 (JRCG); NIH HD-RO1 062803-01A1 (PFR); PCC, MGB, FB, JRCG and PFR worked previously at the CRRWH, Perelman School of Medicine at the University of Pennsylvania, where this study was developed. 


\section{References}

Aitken RJ. Pathophysiology of human spermatozoa. Curr Opin Obstet Gynecol. 1994; 6:128-135. [PubMed: 8193251]

Armon L, Eisenbach M. Behavioral mechanism during human sperm chemotaxis: Involvement of hyperactivation. PLoS ONE. 2011; 6:e28359. [PubMed: 22163296]

Baggiolini M. Chemokines and leukocyte traffic. Nature. 1998; 392:565-568. [PubMed: 9560152]

Benoff S, Hurley I, Cooper GW, Mandel FS, Hershlag A, Scholl GM, Rosenfeld DL. Fertilization potential in vitro is correlated with head-specific mannose-ligand receptor expression, acrosome status and membrane cholesterol content. Hum Reprod. 1993; 8:2155-2166. [PubMed: 8150918]

Buffone MG, Rodriguez-Miranda E, Storey BT, Gerton GL. Acrosomal exocytosis of mouse sperm progresses in a consistent direction in response to zona pellucida. J Cell Physiol. 2009; 220:611620. [PubMed: 19373867]

Burkman LJ. Discrimination between nonhyperactivated and classical hyperactivated motility patterns in human spermatozoa using computerized analysis. Fertil Steril. 1991; 55:363-371. [PubMed: 1991534]

Caballero-Campo P, Domínguez F, Coloma J, Meseguer M, Remohí J, Pellicer A, Simón C. Hormonal and embryonic regulation of chemokines IL-8, MCP-1 and RANTES in the human endometrium during the window of implantation. Mol Hum Reprod. 2002; 8:375-384. [PubMed: 11912286]

Caballero-Campo P, Chirinos M, Fan XJ, González-González ME, Galicia-Chavarría M, Larrea F, Gerton GL. Biological effects of recombinant human zona pellucida proteins on sperm function. Biol Reprod. 2006; 74:760-768. [PubMed: 16407501]

Cohen-Dayag A, Tur-Kaspa I, Dor J, Mashiach S, Eisenbach M. Sperm capacitation in humans is transient and correlates with chemotactic responsiveness to follicular factors. Proc Natl Acad Sci U S A. 1995; 92:11039-11043. [PubMed: 7479932]

Conejo-Garcia JR, Benencia F, Courreges M-C, Kang E, Mohamed-Hadley A, Buckanovich RJ, Holtz DO, Jenkins A, Na H, Zhang L, et al. Tumor-infiltrating dendritic cell precursors recruited by a beta-defensin contribute to vasculogenesis under the influence of Vegf-A. Nat Med. 2004; 10:950958. [PubMed: 15334073]

Cook DN, Prosser DM, Forster R, Zhang J, Kuklin NA, Abbondanzo SJ, Niu XD, Chen SC, Manfra DJ, Wiekowski MT, et al. CCR6 mediates dendritic cell localization, lymphocyte homeostasis, and immune responses in mucosal tissue. Immunity. 2000; 12:495-503. [PubMed: 10843382]

Cubillos-Ruiz JR, Engle X, Scarlett UK, Martinez D, Barber A, Elgueta R, Wang L, Nesbeth Y, Durant Y, Gewirtz AT, et al. Polyethylenimine-based siRNA nanocomplexes reprogram tumorassociated dendritic cells via TLR5 to elicit therapeutic antitumor immunity. J Clin Invest. 2009; 119:2231-2244. [PubMed: 19620771]

Denison FC, Grant VE, Calder AA, Kelly RW. Seminal plasma components stimulate interleukin-8 and interleukin-10 release. Mol Hum Reprod. 1999; 5:220-226. [PubMed: 10333355]

Dominguez F, Pellicer A, Simon C. The chemokine connection: hormonal and embryonic regulation at the human maternal-embryonic interface--a review. Placenta. 2003; 24(Suppl B):S48-55. [PubMed: 14559030]

Eisenbach M. Mammalian sperm chemotaxis and its association with capacitation. Dev Gen. 1999; 25:87-94.

Eisenbach M, Giojalas LC. Sperm guidance in mammals — an unpaved road to the egg. Nat Rev Mol Cell Biol. 2006; 7:276-285. [PubMed: 16607290]

Eisenbach M, Tur-Kaspa I. Do human eggs attract spermatozoa? Bioessays. 1999; 21:203-210. [PubMed: 10333729]

Fabro G, Rovasio RA, Civalero S, Frenkel A, Caplan SR, Eisenbach M, Giojalas LC. Chemotaxis of Capacitated Rabbit Spermatozoa to Follicular Fluid Revealed by a Novel Directionality-Based Assay. Biol Reprod. 2002; 67:1565-1571. [PubMed: 12390889]

García JR, Jaumann F, Schulz S, Krause A, Rodríguez-Jiménez J, Forssmann U, Adermann K, Klüver E, Vogelmeier C, Becker D, et al. Identification of a novel, multifunctional beta-defensin (human beta-defensin 3) with specific antimicrobial activity. Its interaction with plasma membranes of 
Xenopus oocytes and the induction of macrophage chemoattraction. Cell Tissue Res. 2001; 306:257-264. [PubMed: 11702237]

García-Velasco JA, Arici A. Chemokines and human reproduction. Fertil Steril. 1999; 71:983-993. [PubMed: 10360897]

Ghannam S, Dejou C, Pedretti N, Giot J-P, Dorgham K, Boukhaddaoui H, Deleuze V, Bernard FX, Jorgensen C, Yssel H, et al. CCL20 and $\beta$-defensin-2 induce arrest of human Th17 cells on inflamed endothelium in vitro under flow conditions. J Immunol. 2011; 186:1411-1420. [PubMed: 21178014]

Giojalas LC, Rovasio RA. Mouse spermatozoa modify their motility parameters and chemotactic response to factors from the oocyte microenvironment. Int J Androl. 1998; 21:201-206. [PubMed: 9749350]

Greaves DR, Wang W, Dairaghi DJ, Dieu MC, Saint-Vis B, Franz-Bacon K, Rossi D, Caux C, McClanahan T, Gordon S, et al. CCR6, a CC chemokine receptor that interacts with macrophage inflammatory protein 3alpha and is highly expressed in human dendritic cells. J Exp Med. 1997; 186:837-844. [PubMed: 9294138]

Griffiths GS, Miller KA, Galileo DS, Martin-DeLeon PA. Murine SPAM1 is secreted by the estrous uterus and oviduct in a form that can bind to sperm during capacitation: acquisition enhances hyaluronic acid-binding ability and cumulus dispersal efficiency. Reproduction. 2008; 135:293301. [PubMed: 18299422]

Guerrero A, Wood CD, Nishigaki T, Carneiro J, Darszon A. Tuning sperm chemotaxis. Biochem Soc Trans. 2010; 38:1270-1274. [PubMed: 20863297]

Hoover DM, Boulegue C, Yang D, Oppenheim JJ, Tucker K, Lu W, Lubkowski J. The structure of human macrophage inflammatory protein-3alpha /CCL20. Linking antimicrobial and CC chemokine receptor-6-binding activities with human beta-defensins. J Biol Chem. 2002; 277:37647-37654. [PubMed: 12149255]

Isobe T, Minoura H, Tanaka K, Shibahara T, Hayashi N, Toyoda N. The effect of RANTES on human sperm chemotaxis. Hum Reprod. 2002; 17:1441-1446. [PubMed: 12042258]

Jaiswal BS, Tur-Kaspa I, Dor J, Mashiach S, Eisenbach M. Human sperm chemotaxis: is progesterone a chemoattractant? Biol Reprod. 1999; 60:1314-1319. [PubMed: 10330086]

Kaupp UB. 100 years of sperm chemotaxis. J Gen Physiol. 2012; 140:583-586. [PubMed: 23183693]

Kaupp UB, Solzin J, Hildebrand E, Brown JE, Helbig A, Hagen V, Beyermann M, Pampaloni F, Weyand I. The signal flow and motor response controling chemotaxis of sea urchin sperm. Nat Cell Biol. 2003; 5:109-117. [PubMed: 12563276]

Kawano Y, Kawasaki F, Nakamura S, Matsui N, Narahara H, Miyakawa I. The production and clinical evaluation of macrophage colony-stimulating factor and macrophage chemoattractant protein-1 in human follicular fluids. Am J Reprod Immunol. 2001; 45:1-5. [PubMed: 11211941]

Kelly RW. Immunosuppressive mechanisms in semen: implications for contraception. Hum Reprod. 1995; 10:1686-1693. [PubMed: 8582962]

Kim KS, Cha MC, Gerton GL. Mouse sperm protein sp56 is a component of the acrosomal matrix. Biol Reprod. 2001; 64:36-43. [PubMed: 11133656]

King AE, Fleming DC, Critchley HOD, Kelly RW. Differential expression of the natural antimicrobials, beta-defensins 3 and 4, in human endometrium. J Reprod Immunol. 2003; 59:1-16. [PubMed: 12892899]

Laemmli UK. Cleavage of structural proteins during the assembly of the head of bacteriophage T4. Nature. 1970; 227:680-685. [PubMed: 5432063]

Lasso JL, Noiles EE, Alvarez JG, Storey BT. Mechanism of superoxide dismutase loss from human sperm cells during cryopreservation. J Androl. 1994; 15:255-265. [PubMed: 7928668]

Lee SL, Kao CC, Wei YH. Antithrombin III enhances the motility and chemotaxis of boar sperm. Comp Biochem Physiol Comp Physiol. 1994; 107:277-282. [PubMed: 7907959]

Li P, Chan HC, He B, So SC, Chung YW, Shang Q, Zhang Y-D, Zhang Y-L. An antimicrobial peptide gene found in the male reproductive system of rats. Science. 2001; 291:1783-1785. [PubMed: 11230693]

Makler A, Reichler A, Stoller J, Feigin PD. A new model for investigating in real-time the existence of chemotaxis in human spermatozoa. Fertil Steril. 1992; 57:1066-1074. [PubMed: 1572475] 
Mbizvo MT, Burkman LJ, Alexander NJ. Human follicular fluid stimulates hyperactivated motility in human sperm. Fertil Steril. 1990; 54:708-712. [PubMed: 2209894]

Muciaccia B, Padula F, Vicini E, Gandini L, Lenzi A, Stefanini M. Beta-chemokine receptors 5 and 3 are expressed on the head region of human spermatozoon. FASEB J. 2005; 19:2048-2050. [PubMed: 16174786]

Oppermann M. Chemokine receptor CCR5: insights into structure, function, and regulation. Cellular Signalling. 2004; 16:1201-1210. [PubMed: 15337520]

Patil AA, Cai Y, Sang Y, Blecha F, Zhang G. Cross-species analysis of the mammalian beta-defensin gene family: presence of syntenic gene clusters and preferential expression in the male reproductive tract. Physiol Genomics. 2005; 23:5-17. [PubMed: 16033865]

Pérez-Cañadillas JM, Zaballos A, Gutiérrez J, Varona R, Roncal F, Albar JP, Márquez G, Bruix M. NMR solution structure of murine CCL20/MIP-3alpha, a chemokine that specifically chemoattracts immature dendritic cells and lymphocytes through its highly specific interaction with the beta-chemokine receptor CCR6. J Biol Chem. 2001; 276:28372-28379. [PubMed: 11373289]

Quayle AJ, Porter EM, Nussbaum AA, Wang YM, Brabec C, Yip KP, Mok SC. Gene expression, immunolocalization, and secretion of human defensin-5 in human female reproductive tract. Am $\mathrm{J}$ Pathol. 1998; 152:1247-1258. [PubMed: 9588893]

Ralt D, Goldenberg M, Fetterolf P, Thompson D, Dor J, Mashiach S, Garbers DL, Eisenbach M. Sperm attraction to a follicular factor(s) correlates with human egg fertilizability. Proc Natl Acad Sci U S A. 1991; 88:2840-2844. [PubMed: 2011591]

Reif K, Cantrell DA. Networking Rho family GTPases in lymphocytes. Immunity. 1998; 8:395-401. [PubMed: 9586630]

Robertson SA. Seminal fluid signaling in the female reproductive tract: lessons from rodents and pigs. J Anim Sci. 2007; 85:E36-44. [PubMed: 17085725]

Robertson SA, O'Leary S, Armstrong DT. Influence of semen on inflammatory modulators of embryo implantation. Soc Reprod Fertil Suppl. 2006; 62:231-245. [PubMed: 16866321]

Rodríguez-Jiménez FJ, Krause A, Schulz S, Forssmann WG, Conejo-Garcia JR, Schreeb R, Motzkus D. Distribution of new human beta-defensin genes clustered on chromosome 20 in functionally different segments of epididymis. Genomics. 2003; 81:175-183. [PubMed: 12620395]

Röhrl J, Yang D, Oppenheim JJ, Hehlgans T. Specific Binding and Chemotactic Activity of mBD4 and Its Functional Orthologue hBD2 to CCR6-expressing Cells. J Biol Chem. 2010a; 285:70287034. [PubMed: 20068036]

Röhrl J, Yang D, Oppenheim JJ, Hehlgans T. Human beta-defensin 2 and 3 and their mouse orthologs induce chemotaxis through interaction with CCR2. J Immunol. 2010b; 184:6688-6694. [PubMed: 20483750]

Sharkey DJ, Tremellen KP, Jasper MJ, Gemzell-Danielsson K, Robertson SA. Seminal fluid induces leukocyte recruitment and cytokine and chemokine mRNA expression in the human cervix after coitus. J Immunol. 2012; 188:2445-2454. [PubMed: 22271649]

Da Silva N, Cortez-Retamozo V, Reinecker H-C, Wildgruber M, Hill E, Brown D, Swirski FK, Pittet MJ, Breton S. A dense network of dendritic cells populates the murine epididymis. Reproduction. 2011; 141:653-663. [PubMed: 21310816]

Simón C, Mercader A, Frances A, Gimeno MJ, Polan ML, Remohí J, Pellicer A. Hormonal regulation of serum and endometrial IL-1a, IL-1 $\beta$ and IL-1ra: IL-1 endometrial microenvironment of the human embryo at the apposition phase under physiological and supraphysiological steroid level conditions. J Reprod Immunol. 1996; 31:165-184. [PubMed: 8905550]

Simón C, Caballero-Campo P, García-Velasco JA, Pellicer A. Potential implications of chemokines in reproductive function: an attractive idea. J Reprod Immunol. 1998; 38:169-193. [PubMed: 9730290]

Sliwa L. Chemotaction of mouse spermatozoa induced by certain hormones. Arch Androl. 1995; 35:105-110. [PubMed: 8579470]

Soboll G, Schaefer TM, Wira CR. Effect of toll-like receptor (TLR) agonists on TLR and microbicide expression in uterine and vaginal tissues of the mouse. Am J Reprod Immunol. 2006; 55:434-446. [PubMed: 16674601] 
Spehr M, Gisselmann G, Poplawski A, Riffell JA, Wetzel CH, Zimmer RK, Hatt H. Identification of a testicular odorant receptor mediating human sperm chemotaxis. Science. 2003; 299:2054-2058. [PubMed: 12663925]

Suarez SS. Hyperactivated motility in sperm. J Androl. 1996; 17:331-335. [PubMed: 8889694]

Sullivan R, Frenette G, Girouard J. Epididymosomes are involved in the acquisition of new sperm proteins during epididymal transit. Asian J Androl. 2007; 9:483-491. [PubMed: 17589785]

Sun F, Bahat A, Gakamsky A, Girsh E, Katz N, Giojalas LC, Tur-Kaspa I, Eisenbach M. Human sperm chemotaxis: both the oocyte and its surrounding cumulus cells secrete sperm chemoattractants. Hum Reprod. 2005; 20:761-767. [PubMed: 15591080]

Taylor K, Rolfe M, Reynolds N, Kilanowski F, Pathania U, Clarke D, Yang D, Oppenheim J, Samuel $\mathrm{K}$, Howie S, et al. Defensin-related peptide 1 (Defr1) is allelic to Defb8 and chemoattracts immature DC and CD4+ T cells independently of CCR6. Eur J Immunol. 2009; 39:1353-1360. [PubMed: 19404978]

Teves ME, Guidobaldi HA, Uñates DR, Sanchez R, Miska W, Giojalas LC. Progesterone sperm chemoattraction may be modulated by its corticosteroid-binding globulin carrier protein. Fertil Steril. 2010; 93:2450-2452. [PubMed: 19896663]

Tollner TL, Yudin AI, Treece CA, Overstreet JW, Cherr GN. Macaque sperm coating protein DEFB126 facilitates sperm penetration of cervical mucus. Hum Reprod. 2008a; 23:2523-2534. [PubMed: 18658160]

Tollner TL, Yudin AI, Tarantal AF, Treece CA, Overstreet JW, Cherr GN. Beta-defensin 126 on the surface of macaque sperm mediates attachment of sperm to oviductal epithelia. Biol Reprod. 2008b; 78:400-412. [PubMed: 18003946]

Tollner TL, Venners SA, Hollox EJ, Yudin AI, Liu X, Tang G, Xing H, Kays RJ, Lau T, Overstreet JW, et al. A common mutation in the defensin DEFB126 causes impaired sperm function and subfertility. Sci Transl Med. 2011; 3:92ra65.

Tollner TL, Bevins CL, Cherr GN. Multifunctional glycoprotein DEFB126--a curious story of defensin-clad spermatozoa. Nat Rev Urol. 2012; 9:365-375. [PubMed: 22710670]

Towbin H, Staehelin T, Gordon J. Electrophoretic transfer of proteins from polyacrylamide gels to nitrocellulose sheets: procedure and some applications. Proc Natl Acad Sci U S A. 1979; 76:43504354. [PubMed: 388439]

Turner RM, Eriksson RL, Gerton GL, Moss SB. Relationship between sperm motility and the processing and tyrosine phosphorylation of two human sperm fibrous sheath proteins, prohAKAP82 and hAKAP82. Mol Hum Reprod. 1999; 5:816-824. [PubMed: 10460219]

Turner RM, Foster JA, Gerton GL, Moss SB, Patrizio P. Molecular evaluation of two major human sperm fibrous sheath proteins, pro-hAKAP82 and hAKAP82, in stump tail sperm. Fertil Steril. 2001; 76:267-274. [PubMed: 11476771]

Valore EV, Park CH, Quayle AJ, Wiles KR, McCray PB Jr, Ganz T. Human beta-defensin-1: an antimicrobial peptide of urogenital tissues. J Clin Invest. 1998; 101:1633-1642. [PubMed: 9541493]

Varona R, Zaballos A, Gutiérrez J, Martín P, Roncal F, Albar JP, Ardavín C, Márquez G. Molecular cloning, functional characterization and mRNA expression analysis of the murine chemokine receptor CCR6 and its specific ligand MIP-3alpha. FEBS Lett. 1998; 440:188-194. [PubMed: 9862452]

Varona R, Villares R, Carramolino L, Goya I, Zaballos A, Gutiérrez J, Torres M, Martínez-A C, Márquez G. CCR6-deficient mice have impaired leukocyte homeostasis and altered contact hypersensitivity and delayed-type hypersensitivity responses. J Clin Invest. 2001; 107:R37-45. [PubMed: 11254677]

Villanueva-Diaz C, Vadillo-Ortega F, Kably-Ambe A, Diaz-Pérez MA, Krivitzky SK. Evidence that human follicular fluid contains a chemoattractant for spermatozoa. Fertil Steril. 1990; 54:11801182. [PubMed: 2245848]

Visconti PE, Galantino-Homer H, Moore GD, Bailey JL, Ning X, Fornes M, Kopf GS. The molecular basis of sperm capacitation. J Androl. 1998; 19:242-248. [PubMed: 9570749]

Visconti PE, Krapf D, de la Vega-Beltran JL, Acevedo JJ, Darszon A. Ion channels, phosphorylation and mammalian sperm capacitation. Asian J Androl. 2011; 13:395-405. [PubMed: 21540868] 
Ward SG, Westwick J. Chemokines: understanding their role in T-lymphocyte biology. Biochem J. 1998; 333(Pt 3):457-470. [PubMed: 9677302]

World Health Organization. WHO laboratory manual for the examination and processing of human semen. Geneva: World Health Organization; 2010.

Yanagimachi, R. Mammalian fertilization. In: Knobil, E.; Neill, JD., editors. The Physiology of Reproduction. New York: Raven Press; 1994.

Yang D, Chertov O, Bykovskaia SN, Chen Q, Buffo MJ, Shogan J, Anderson M, Schröder JM, Wang JM, Howard OMZ, et al. $\beta$-Defensins: Linking Innate and Adaptive Immunity Through Dendritic and T Cell CCR6. Science. 1999; 286:525-528. [PubMed: 10521347]

Yudin AI, Generao SE, Tollner TL, Treece CA, Overstreet JW, Cherr GN. Beta-defensin 126 on the cell surface protects sperm from immunorecognition and binding of anti-sperm antibodies. Biol Reprod. 2005; 73:1243-1252. [PubMed: 16079310]

Zeyneloglu HB, Senturk LM, Seli E, Oral E, Olive DL, Arici A. The role of monocyte chemotactic protein-1 in intraperitoneal adhesion formation. Hum Reprod. 1998; 13:1194-1199. [PubMed: 9647546]

Zhang Q, Shimoya K, Temma K, Kimura T, Tsujie T, Shioji M, Wasada K, Fukui O, Hayashi S, Kanagawa T, et al. Expression of fractalkine in the Fallopian tube and of CX3CR1 in sperm. Hum Reprod. 2004; 19:409-414. [PubMed: 14747189]

Zigmond SH. Ability of polymorphonuclear leukocytes to orient in gradients of chemotactic factors. J Cell Biol. 1977; 75:606-616. [PubMed: 264125]

Zuccarello D, Ferlin A, Garolla A, Menegazzo M, Perilli L, Ambrosini G, Foresta C. How the human spermatozoa sense the oocyte: a new role of SDF1-CXCR4 signalling. Int J Androl. 2011; 34:e554-565. [PubMed: 21623830] 


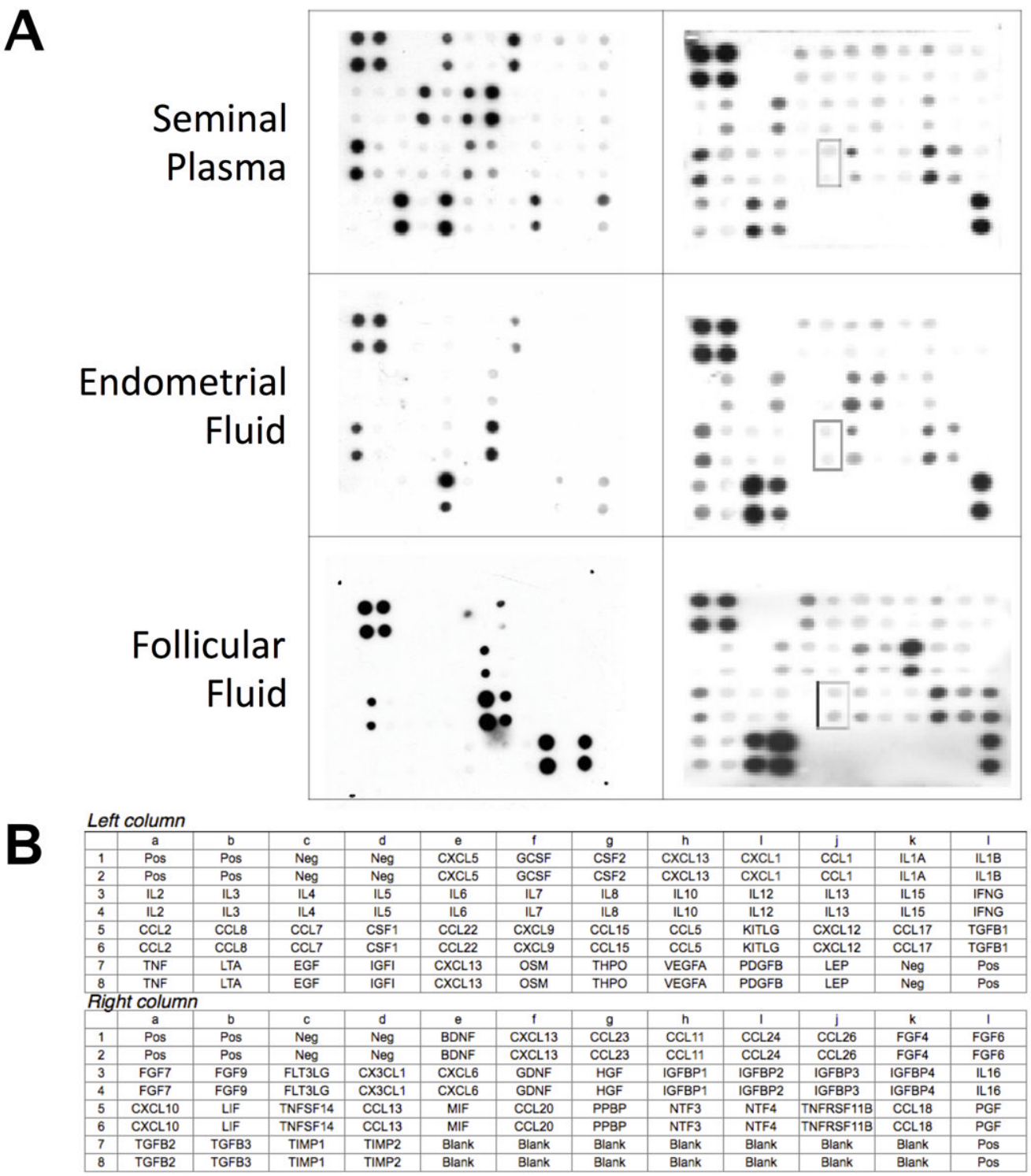

Figure 1.

Human cytokine antibody arrays detected the presence of several chemokines in male and female reproductive tract fluids. Each membrane contained three or more duplicate negative controls, which generated background signals, and three positive controls against which all signals were normalized. The remaining dots corresponded to the 42 or 38 cytokines/ chemokines in duplicate. Seminal plasma, endometrial fluid and follicular fluid exhibited the specific CCR6 ligand CCL20. In addition, CXCL8, RANTES, Fraktalkine, SDF1, and IGF-1 were also found. These are ligands and receptors that have been reported to be involved in sperm motility (see text). 


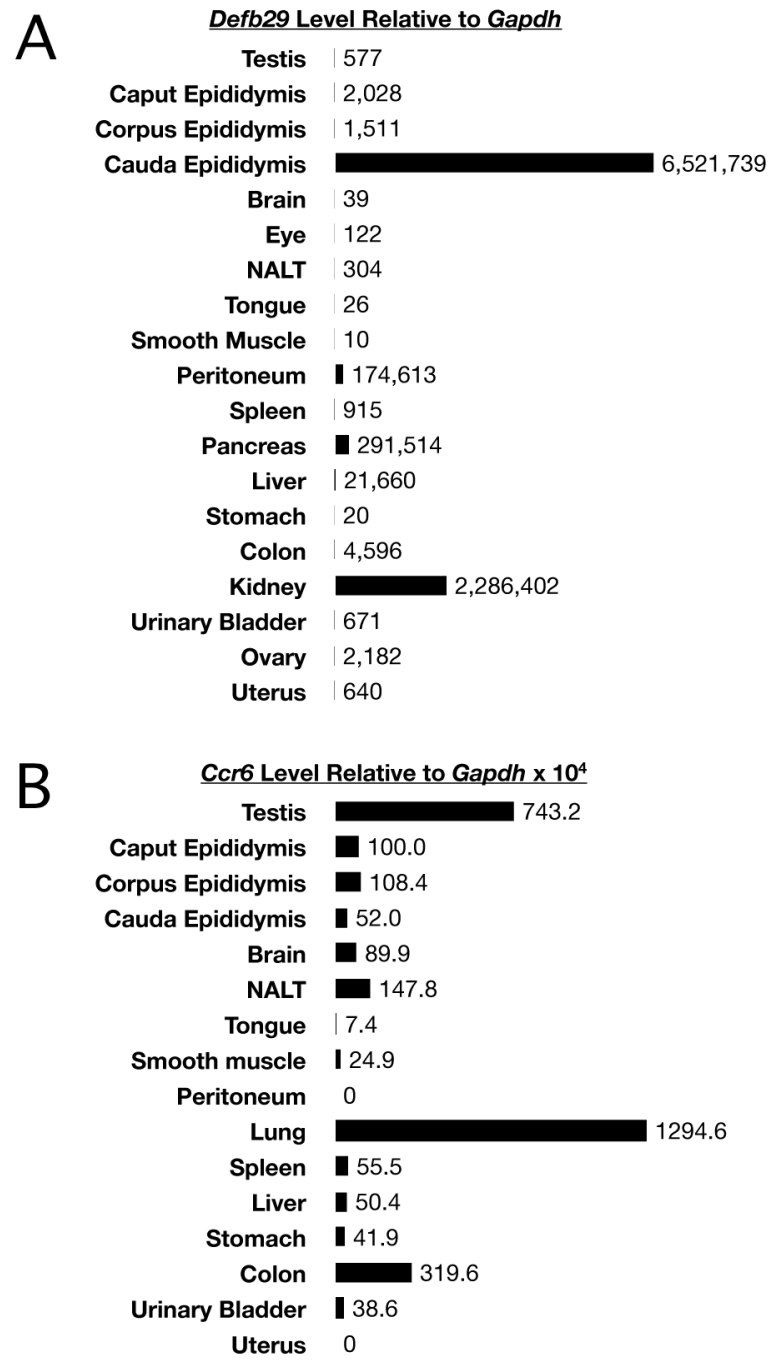

Figure 2.

As detected by quantitative real-time PCR analysis, Defb29 and Ccr6 mRNAs were expressed in the mouse male reproductive tract. A. Defb 29 in the cauda epididymis was very highly expressed relative to different tissues. Levels were about 3 times higher than kidney and over 20-25 times higher than found for peritoneum. Most other tissues expressed Defb29 at much lower but detectable levels. B. Ccr6 mRNA was highly expressed in testis, lung, colon, and dendritic cells (positive control). 

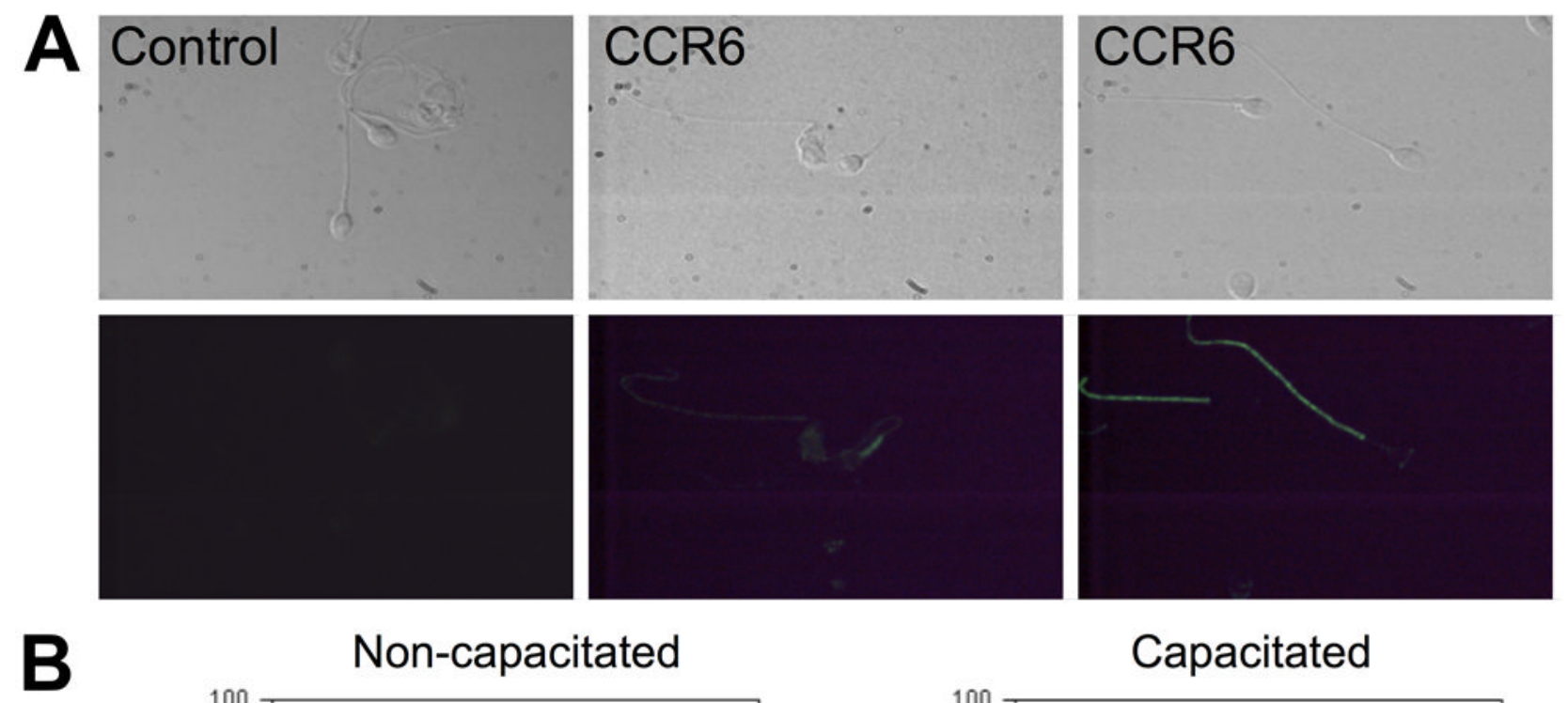

Non-capacitated

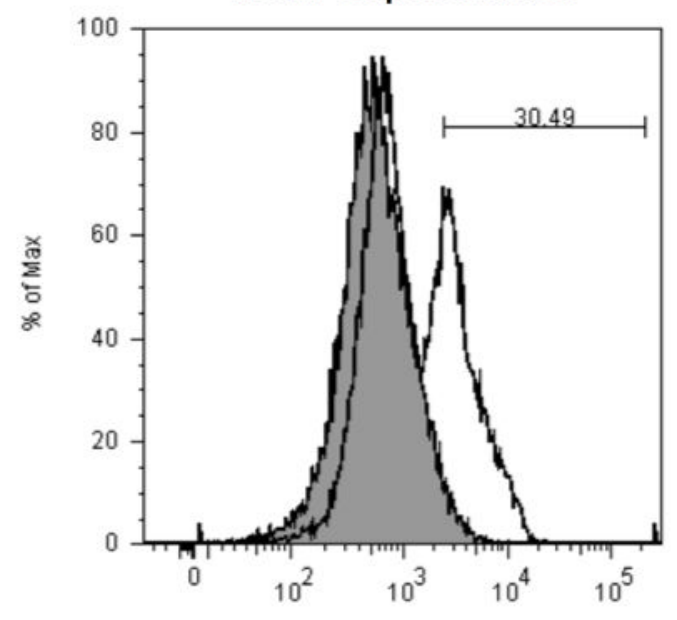

Capacitated

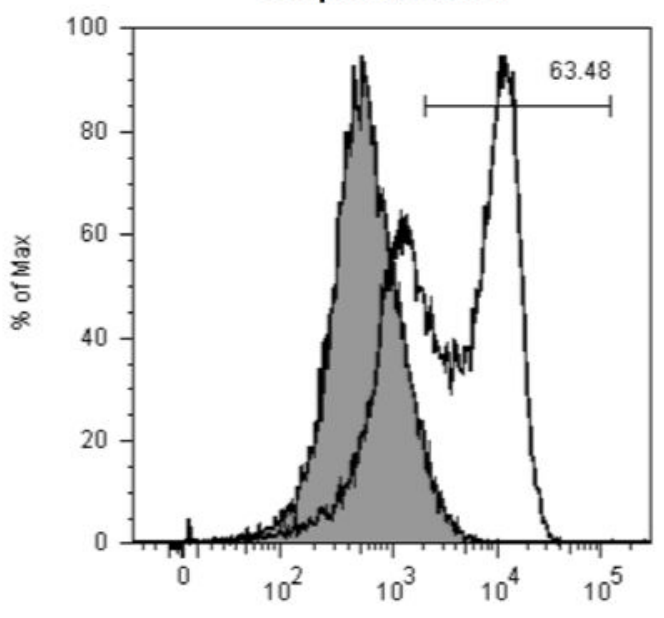

Figure 3.

CCR6 is localized mainly in the flagellum of human sperm. A. Indirect immunofluorescence revealed two different patterns of localization of CCR6 in human sperm. The fluorescence signal was mainly in the tail (principal piece), whereas few sperm showed staining in the midpiece and basal region (neck) area. This localization was not found in the complete sperm population. Photographs above correspond to paired brightfield images. Sperm incubated without first antibody in $10 \%$ normal goat serum displayed negligible staining, and white blood cells were used as a positive control (data not shown). B. Flow Cytometry analysis was performed to quantify the amount of CCR6 on the surfaces of individual sperm cells. The protein was not detected in every sperm. The distribution of fluorescence emission intensity identified two different subpopulations in human sperm. Importantly, capacitating conditions increased the percentage of sperm cells positive for CCR6. 

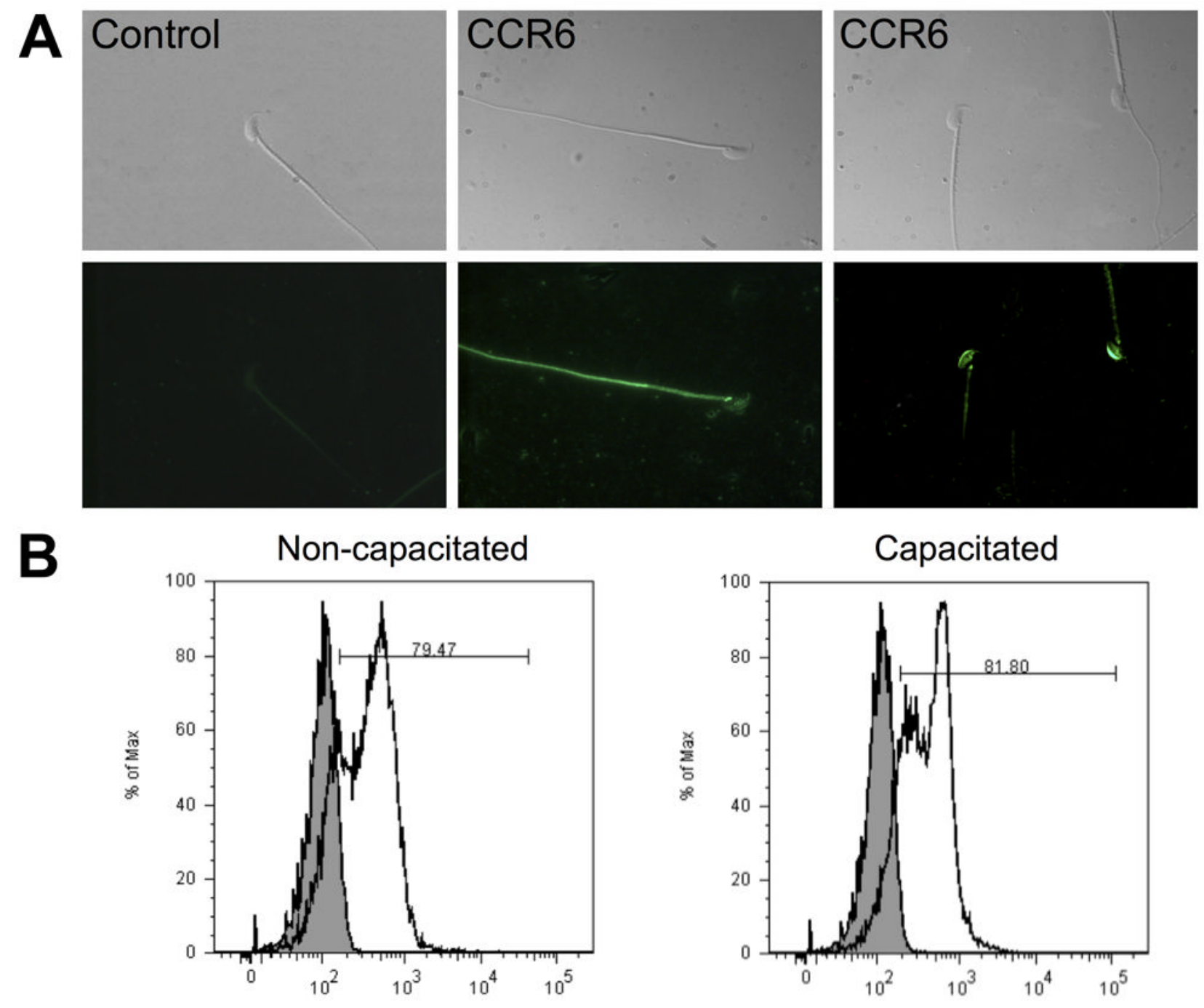

Figure 4.

Mouse sperm CCR6 is found principally in the flagellum. A. Indirect immunofluorescence for mouse cauda epididymal sperm showed two different patterns of localization for the chemokine receptor CCR6. Localization in mouse sperm from cauda epididymis was mainly restricted to the principal piece of the tail and neck, although a few sperm showed staining in the acrosomal area. Photographs above correspond to paired brightfield images. B.

Capacitating conditions did not increase the percentage of mouse sperm positive cells for CCR6, as determined by flow cytometry. 

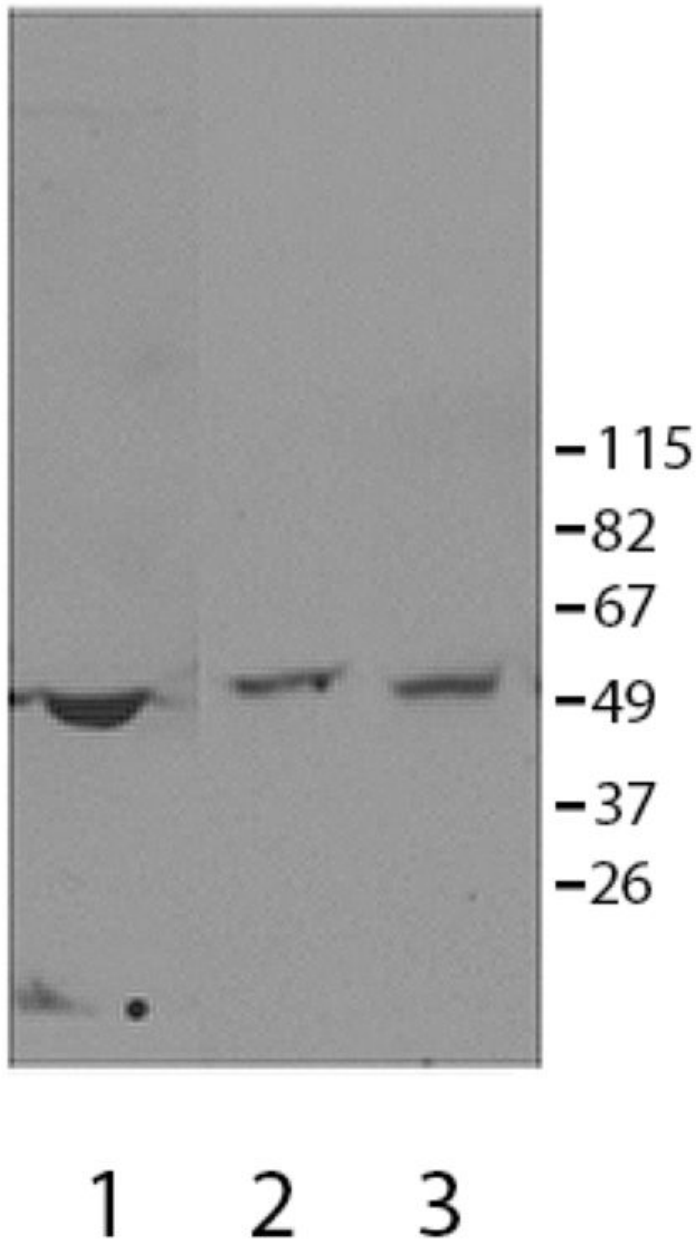

Figure 5.

CCR6 was present in human and mouse sperm as determined by immunoblotting. In human (lane 2) and mouse (lane 3) sperm extracts. The anti-peptide CCR6 antibody identified an immunoreactive band with a molecular weight of approximately 50,000 Mr) (expected molecular weight $\sim 42,000 \mathrm{Mr}$ ). Depending on the experimental conditions, other minor bands were also recognized by this antibody, suggesting that the protein may undergo posttranslational modification. Mouse spleen extracts (lane 1) and human white blood cells (not shown) served as positive controls for the detection of CCR6. 


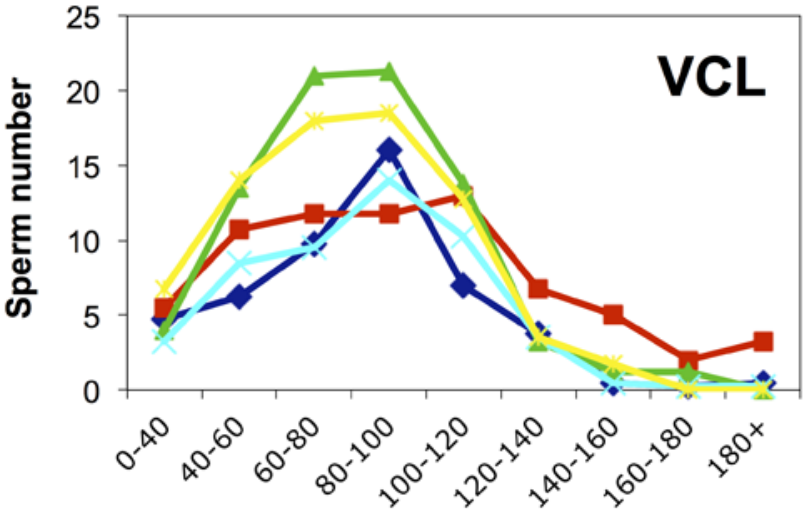

VCL range $(\mu \mathrm{m} / \mathrm{sec})$

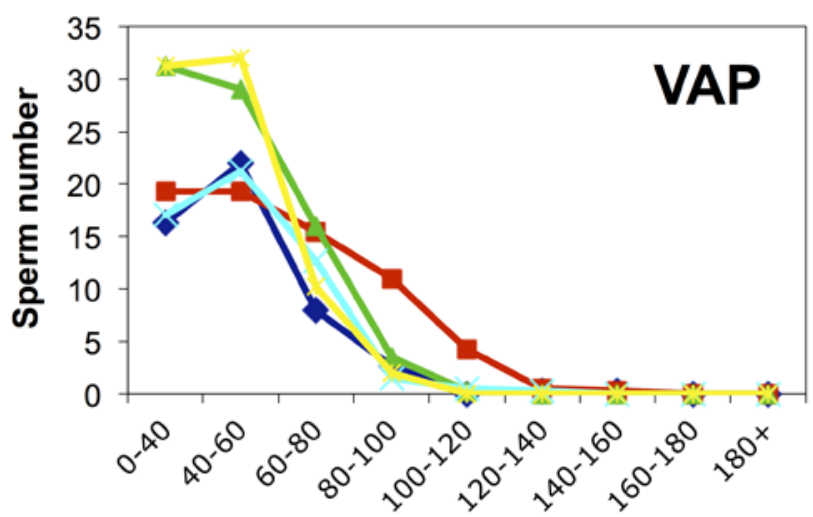

VAP range $(\mu \mathrm{m} / \mathrm{sec})$

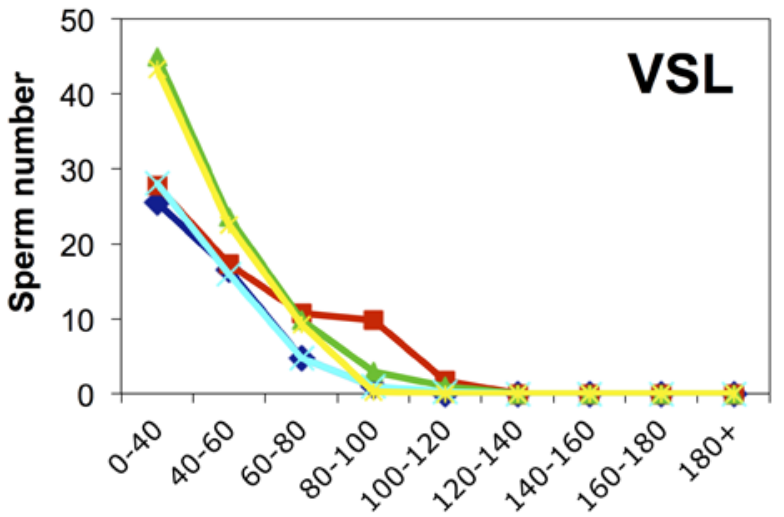

VSL range $(\mu \mathrm{m} / \mathrm{sec})$

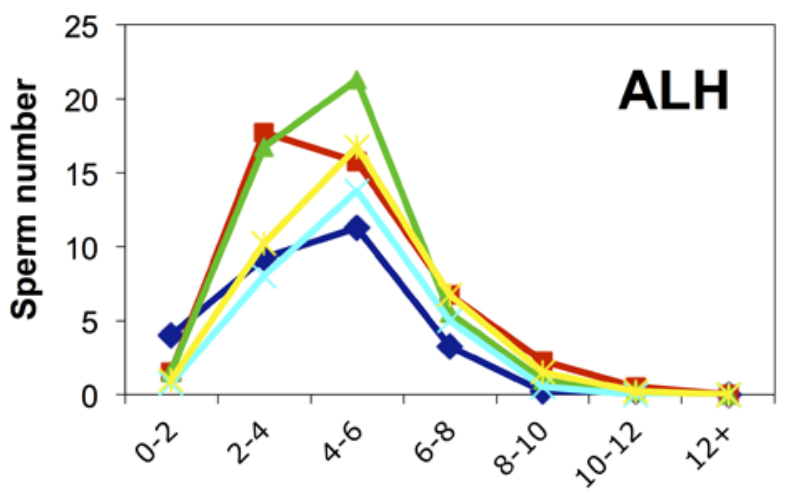

ALH range $(\mu \mathrm{m})$ DEFB2 - DEFB3

Figure 6.

Effect of CCR6 ligands (CCL20, DEFB4 [also known DEFB2], DEFB113A [DEFB4]) on

CASA frequency distribution of motility parameters. After CCL20 treatment, CASA detected an increase in the number of sperm with high values of the progressive (i.e., linear) motility parameters VAP (average path velocity) and VSL (straight line velocity). FF treatment elicited a greater number of sperm with high values of the non-progressive parameters curvilinear velocity (VCL > $120 \mu \mathrm{m} / \mathrm{sec}$ ) and amplitude of lateral head displacement $(\mathrm{ALH}>6 \mu \mathrm{m})$, which characterized the hyperactivated pattern (Burkman, 1991). ( $\mathrm{n}=4$ independent experiments). 

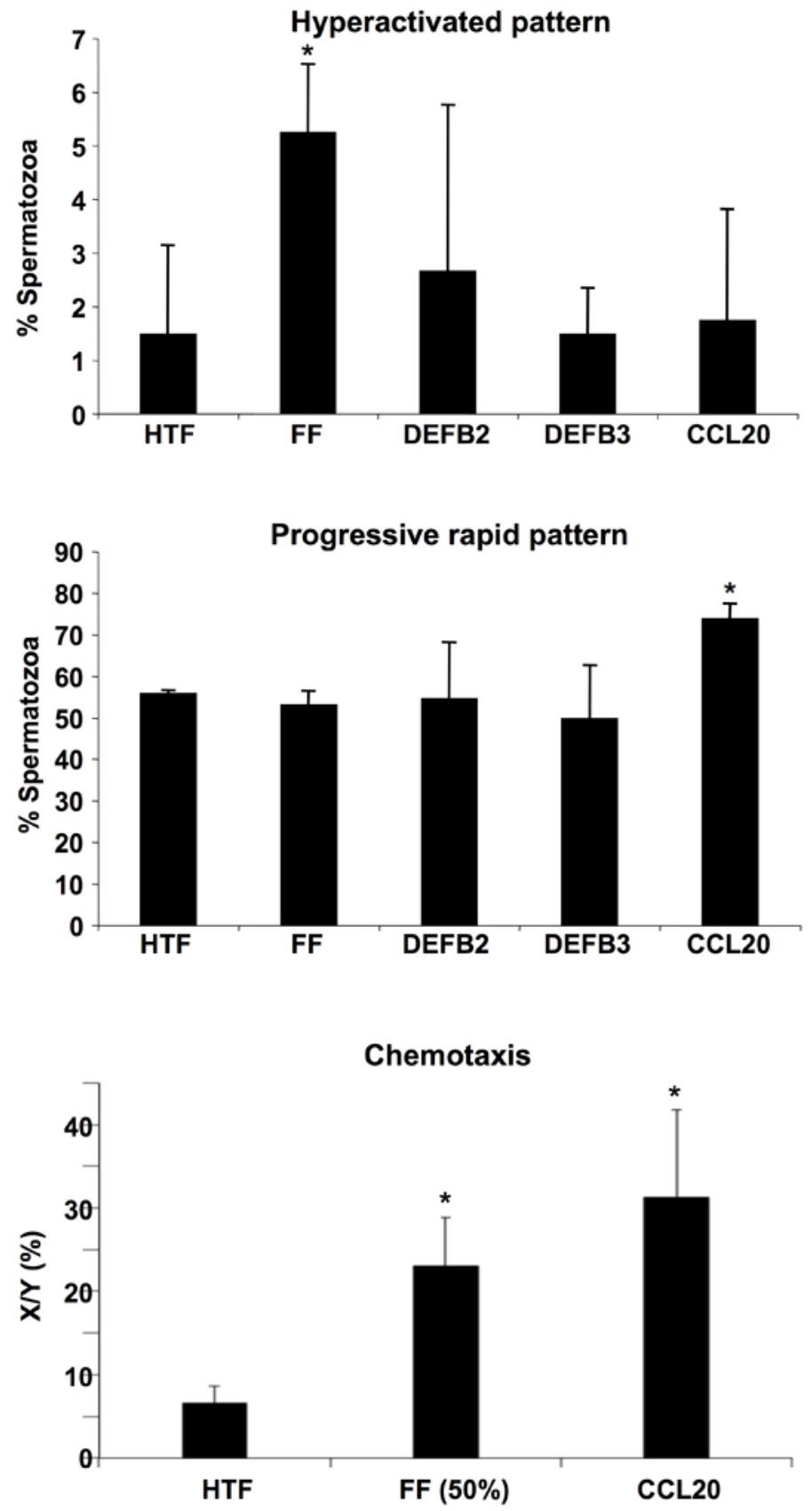

Figure 7.

Sperm motility evaluation in response to CCL20 showed changes in the progressive rapid pattern and evidence of chemotaxis. A. The percentage of spermatozoa showing a hyperactivated pattern is higher after FF treatment compared to HTF (control). No statistically significant differences were found after CCR6 ligand treatments (CCL20, DEFB4 [DEFB2], DEFB113A). B. Percentage analysis after CCL20 showed an increase in the percentage of spermatozoa with progressive rapid motility. $\mathrm{C}$. The percentage of cells showing a chemotactic response was higher in the CCL20 treatment than control HTF. ( $n=4$ independent experiments, statistically significant $\mathrm{p}<0.05)$. 
Table 1

Semi-Quantitative Analysis of Chemokines in Reproductive Fluids and Receptors in Mammalian Sperm

\begin{tabular}{|l|c|c|c|}
\hline & Seminal Plasma & Endometrial Fluid & Follicular Fluid \\
\hline IL-8 & +++ & ++ & ++ \\
\hline CCL2/MCP-1 & +++ & ++ & +++ \\
\hline CCL5/Rantes & - & - & +++ \\
\hline CXC3CL1/Fraktalkine & ++ & ++ & ++ \\
\hline CCL20/MIP-3a & ++ & + & ++ \\
\hline
\end{tabular}

The relative expression levels in protein arrays ranged from no detectable amounts (-) to intensely positive (+++). Positive controls were used to validate the results from different membranes. Results are representative from at least three different samples. 